九州大学学術情報リポジトリ

Kyushu University Institutional Repository

\title{
The Spatial Integration of Vegetable Markets in Myanmar
}

Myae, Aye Chan

Department of Agricultural Planning, Ministry of Agriculture and Irrigation, Myanmar

Yutaka, Tomoyuki

Faculty of Agriculture, Kyushu Unviersity

Fukuda, Susumu

Faculty of Agriculture, Kyushu Unviersity

Kai, Satoshi

Faculty of Agriculture, Kyushu Unviersity

https://doi.org/10.5109/4679

出版情報: 九州大学大学院農学研究院紀要. 50 (2)，pp.665-683，2005-10-01. Faculty of Agriculture, Kyushu University

バージョン :

権利関係 : 


\title{
The Spatial Integration of Vegetable Markets in Myanmar
}

\author{
Aye Chan Myae', Tomoyuki YUTAKA, Susumu FUKUDA \\ and Satoshi KAI* \\ Laboratory of Agricultural Marketing, Division of Industrial Organization of Agribusiness, \\ Department of Agricultural and Resource Economics, Faculty of Agriculture, \\ Kyushu University, Fukuoka 812-8581, Japan \\ (Received June 30, 2005 and accepted July 26, 2005)
}

\begin{abstract}
This study focuses on an empirical test to verify whether price patterns in different locations cohere in Myanmar. Using weekly data for 3 years, the extent of integration, defined as a set of markets that shares common long-run price information, and the causal relationships among markets have been tested within Johansen's co-integration framework. Dynamics of short-run price responses are examined by using vector error correction model (VECM). The results indicated that the higher the perishability, the lesser the integration was. The transit markets and consumption markets were highly integrated. However, the prices of production area and consumption area were not highly integrated. By examining the short-run price adjustment, it could be found that almost all markets reacted on the long-run co-integrating equations, and the most consumption markets reacted the highest on the deviation from long-run equilibrium. Moreover, it could be found that the longer the distance, the weaker the integration was. It can be suggested that if market infrastructure-including transportation, other marketing facilities, and market information, are highly improved, the market efficiency would be better, giving guarantee of profitable vegetable marketing in Myanmar.
\end{abstract}

\section{INTRODUCTION}

Myanmar is one of the developing countries in the South-East Asia region. Agriculture plays the primary role for self-sufficiency in national food requirements, for adequate production of raw materials for local agro-based industries, and for the generation of substantial surplus for export. Since Myanmar is richly endowed with natural resources, there is a great potential for further development in the agriculture sector.

Agricultural development plans have prioritized agriculture as the main sector of the economy with three main objectives; 1) to achieve surplus in paddy production, 2) to achieve self-sufficiency in edible oil, 3) to step up the production of exportable pulses and industrial crops. In order to increase the foreign exchange sector which basically supports the national economy, concerted efforts are being made for increased production of four major crops, namely-paddy, pulses, cotton and sugarcane, recognizing as main pillars. Efforts are also being made to promote the export earning from rubber, coffee, tea and sericulture. The effort for the promotion of fruits and vegetables production is very weak compared to the above crops and the aim is only for domestic consumption. The percentage of crop sown area can be seen in figure (1).

According to agro-ecological zones, some mountainous areas, especially southern

${ }^{1}$ Department of Agricultural Planning, Ministry of Agriculture and Irrigation, Myanmar.

* Corresponding author (E-mail: satokai@agr.kyushu-u.ac.jp) 


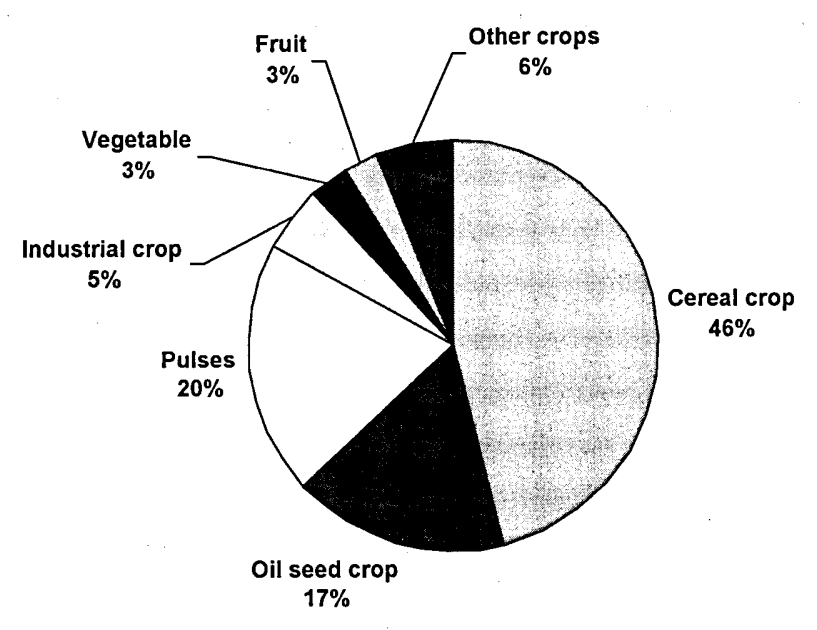

Source : Settlement and Land Record Department, Ministry of Agriculture and Irrigation, Myanmar

Fig. 1. Different crops sown area in Myanmar (2001-02)

Shan State is the main producing area of vegetables, during the rainy season. Thus, consumers in lowland area rely on the supply of highland produce, such as tomato, cabbage, cauliflower, carrot and choko. Accordingly, the prices of these vegetables are high for the additional transportation cost. However, in the cool season, these are grown at lowland area and cheaper for a short-distant transportation cost. Some vegetables are seasonally supplied to local market and some can be found throughout the year. All vegetables are consumed domestically and only a small quantity is exported. The interstate/division trade flow ${ }^{1}$ in large scale of some selected crops in Myanmar can be seen in the figures $2 \mathrm{a}$ to $2 \mathrm{~d}$.

As these figures show, Myanmar can produce some vegetables the whole year round due to its many variations in climatic and geographical conditions. But due to the long-distance transportation cost, the price is changing seasonally.

The nature of markets and their role in price determination are central to economics. Spatial price behavior in regional markets is an important indicator of overall market performance. Typically, agricultural products are bulky and/or perishable and areas of production and consumption are separated; hence, transportation is costly. In order to measure supply and demand, price discovery, and the structure of competition, geographical boundaries of a market are important. The geographical integration of markets determines the extent to which weather risk is shared over space by smoothing idiosyncratic price variations. Integrated markets have limited price differences in time, form and space, to the marketing costs. Tomek and Robinson (1990) mentioned that markets

\footnotetext{
${ }^{1}$ Reference : 1) "Agricultural Marketing in Myanmar", Ministry of Agriculture and Irrigation, Market Information Service Project, TCP/MYA/8821, October, 2000.

2) "Observation from survey conducted in June, 2004.
} 


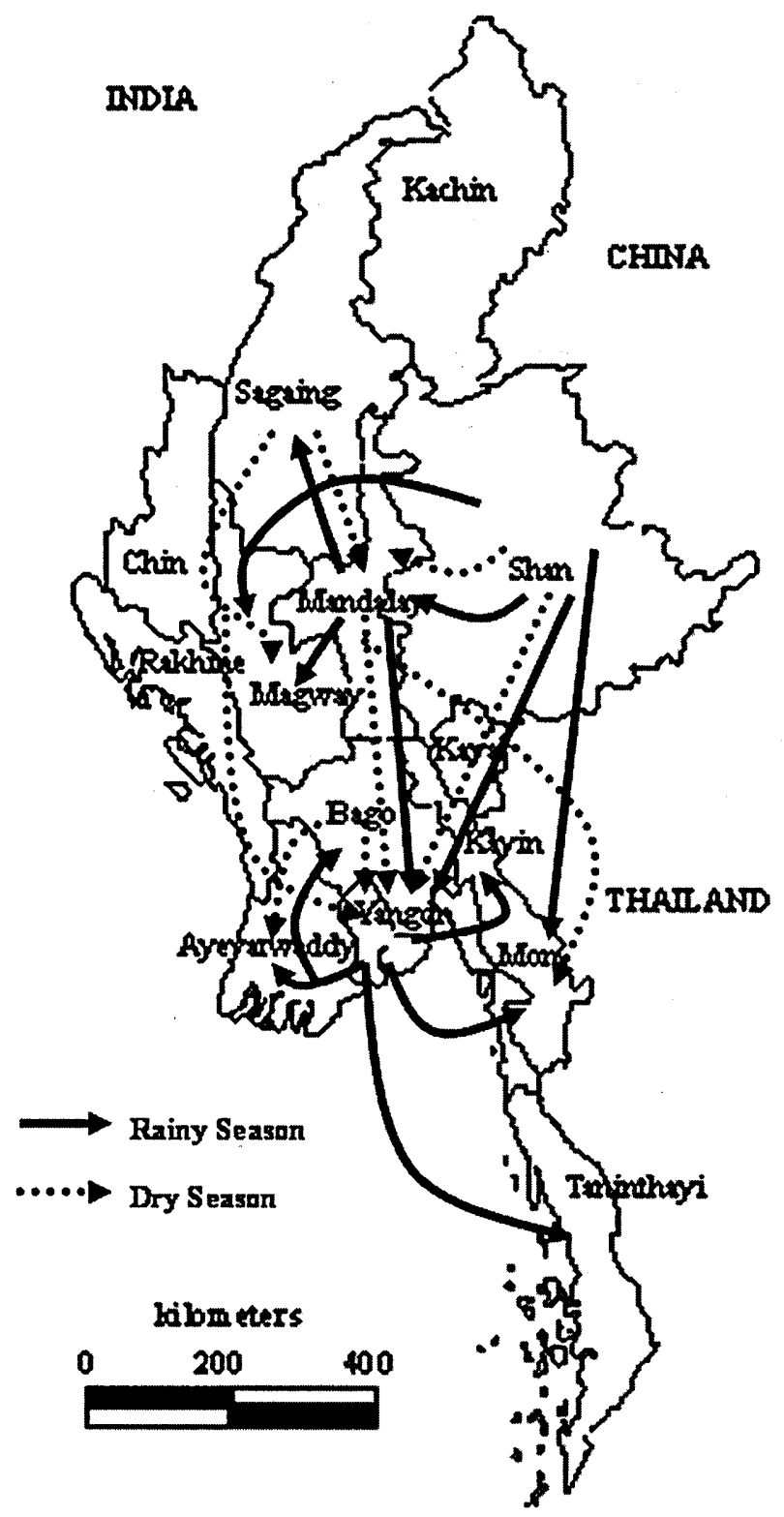

Fig. 2a. The observation of Inter State/Division Trade Flow in Large Scale (Tomato) 


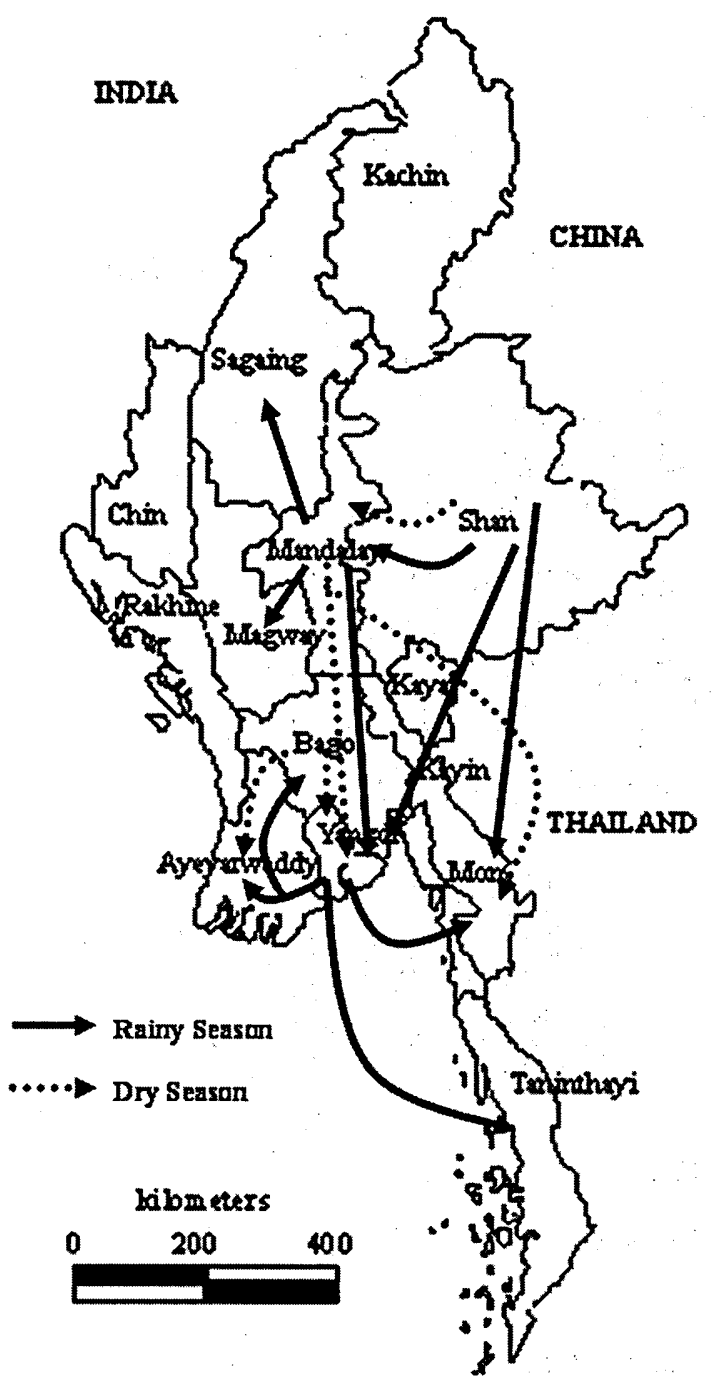

Fig. 2b. The observation of Inter State/Division Trade Flow in Large Scale (Cabbage) 


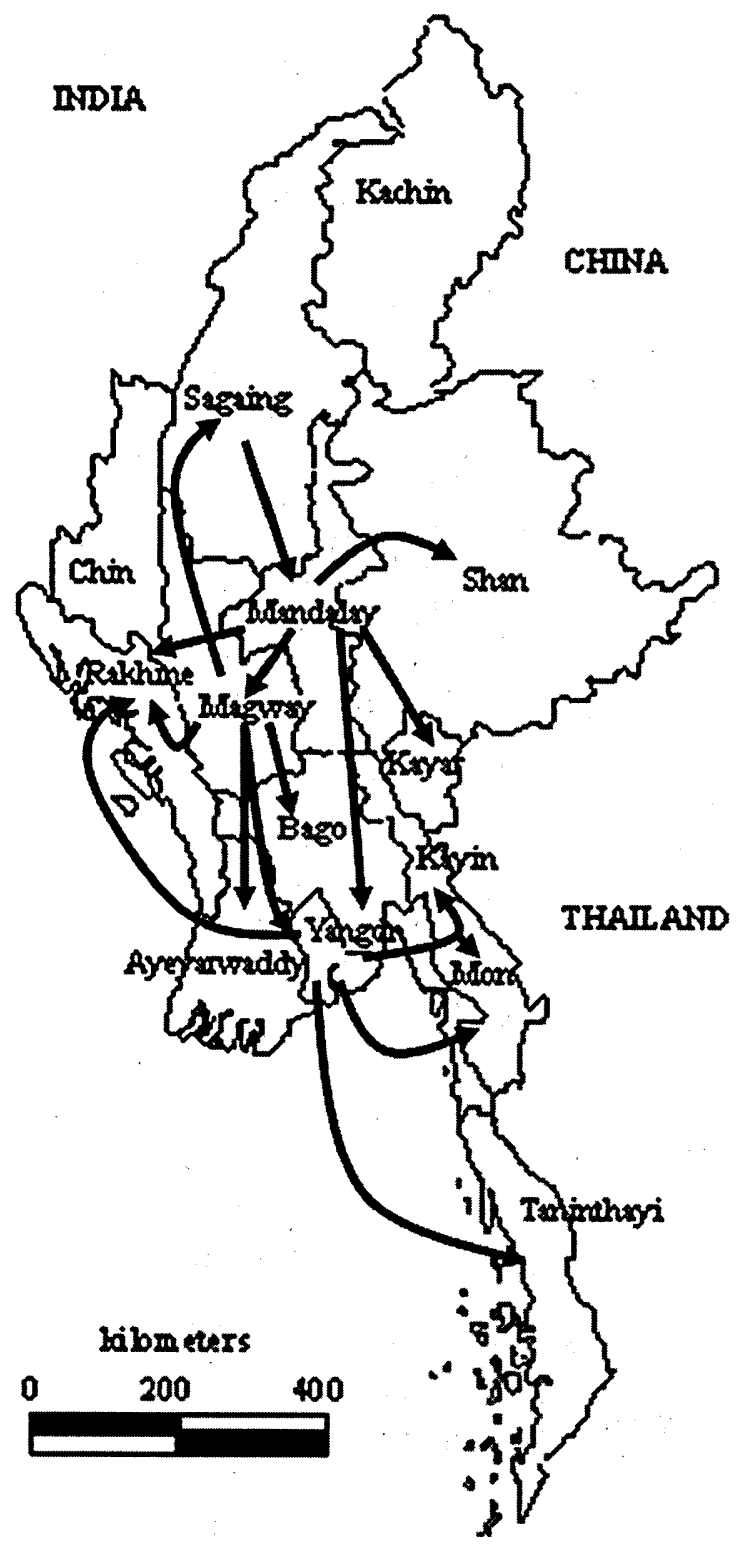

Fig. 2c. The observation of Inter State/Division Trade Flow in Large Scale (Onion) 


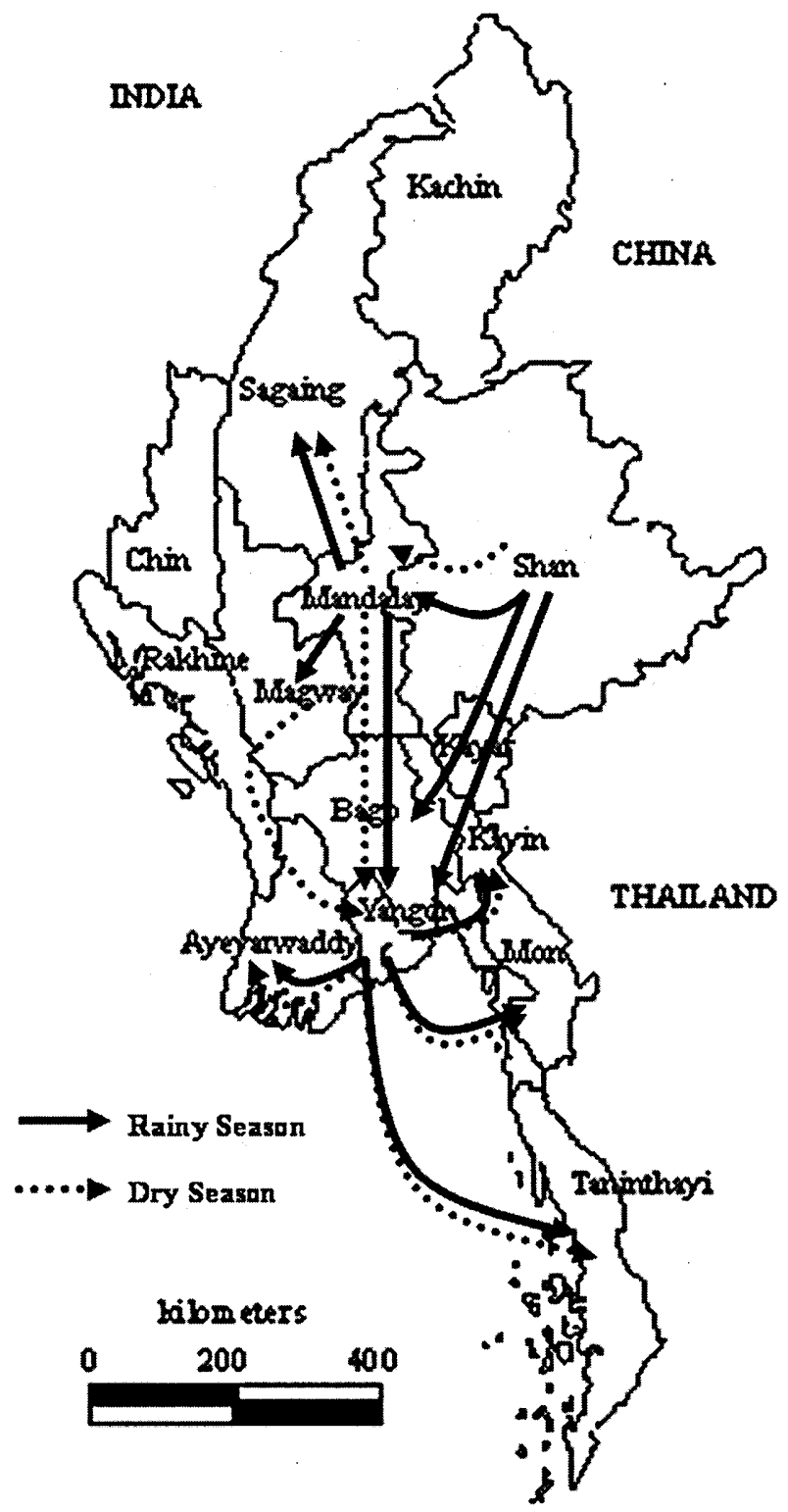

Fig. 2d. The observation of Inter State/Division Trade Flow in Large Scale (Potato) 
which are not integrated may convey inaccurate price information, distorting the marketing decisions of producers and contributing to inefficient product movements. For the prevention of entitlement failures, market integration is also critical. Three reasons for a lack of market integration: 1) prohibitive transaction costs; 2) different kinds of trading barriers; and 3) imperfect competition; are identified by Sexton et al. (1991).

The concept of cointegration was first introduced by Granger (1981) and elaborated further by Engle and Granger (1987), Engle and Yoo (1987, 1991), Phillips and Ouliaris (1990), Stock and Watson (1988), Phillips (1991) and Johansen (1988, 1991, 1994), among others (Bierens, 1997). Moreover, Ravallion (1986), Alexander and Wyeth (1994), and Kuiper et al. (1999) developed different methods to analyze spatial price-differences and to test for market integration.

This paper attempts to fulfill the knowledge about the extent and nature of vegetable market integration in Myanmar. An empirical test is developed to verify whether price patterns in different locations of different characteristics, cohere. Price adjustment process in the long-run and short-run are distinguished. As localized supply shortages and price volatility, resulting from inadequate infrastructure and information asymmetry, were frequent challenge to the policy maker in Myanmar, this appears to be a likely hypothesis.

The rest of the paper is organized as follows. The next section mentions the descriptions of data and their movement in the period 2002-2004, which is followed by a formal description of the methodology. Then the results of the tests along with some discussion on their potential implications are discussed. The paper concludes with a summary of the analysis and some concluding remarks.

\section{DESCRIPTIONS OF THE DATA AND THEIR MOVEMENT}

In Myanmar, daily price was available for only a few market places. Therefore, weekly price series for three years, from 2002 January to 2004 December, were used. The analysis was based on average wholesale price series. Six market places were chosen from the northern part to Southern part of Myanmar: Aung-ban market (AB) from Southern Shan State; Mandalay market (MDY) from Mandalay division; Pyay market (PYAY) and Wetpoke (WP) market from Bago Division; Yangon market (YGN) from Yangon division; and Mawlamyine market (MLM) from Mon State. The wholesale price series were collected from the monthly price bulletin, published by Market Information Service Project, Department of Agricultural Planning, Ministry of Agriculture and Irrigation.

The movement of price series of some selected crops in different markets for three years can be observed by the figures $3 \mathrm{a}$ to $3 \mathrm{~d}$.

Generally, these figures show that almost all price series are following the same pattern. The price of production areas - $A B$, and WP - was well below the price of consumption areas - YGN, MDY, MLM. For being deficit area, the price of most vegetables in MLM were the highest with the additional transportation and transaction costs. 


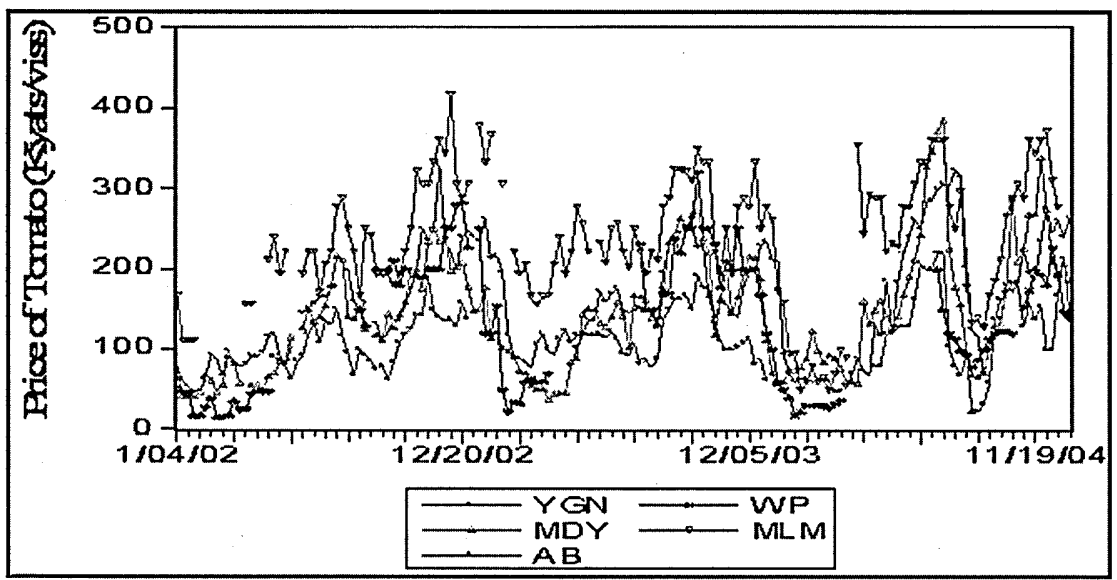

Fig. 3a. Tomato price series of different market places, 2002-2004

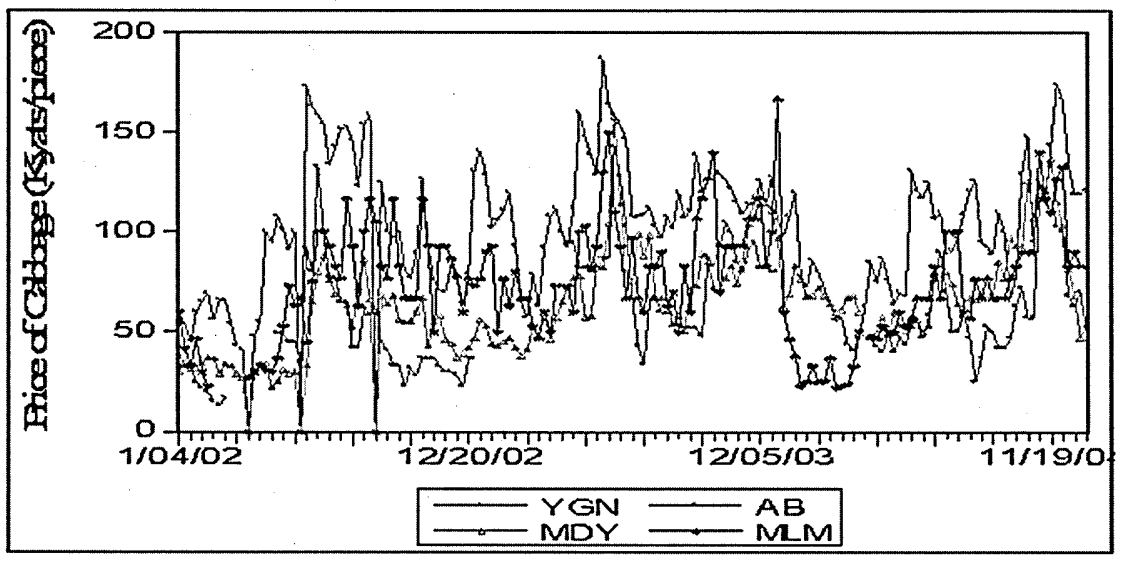

Fig. 3b. Cabbage price series of different market places, 2002-2004 


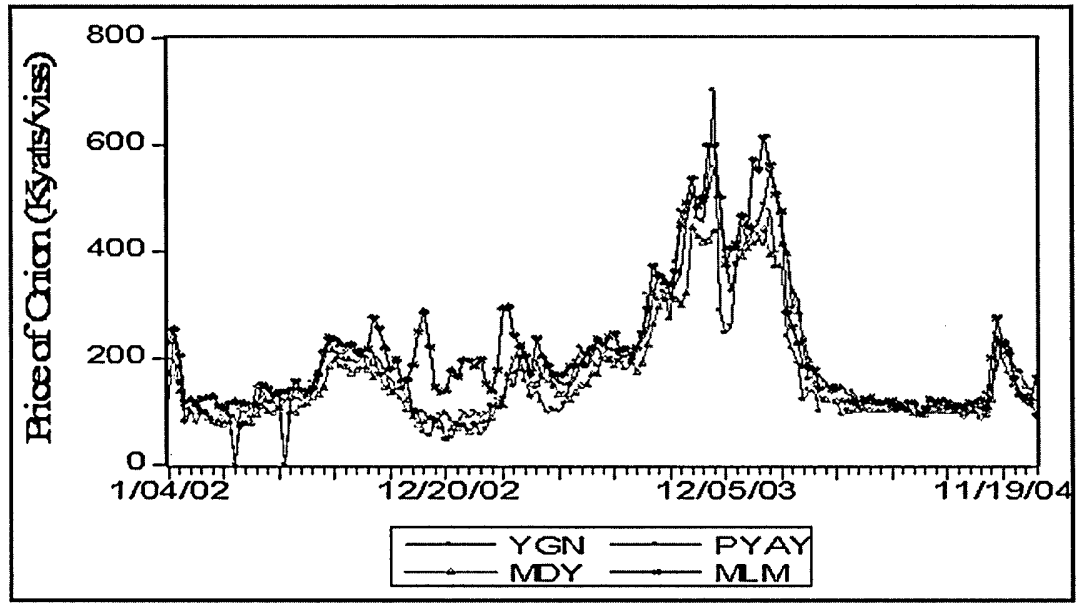

Fig. 3c. Onion price series of different market places, 2002-2004

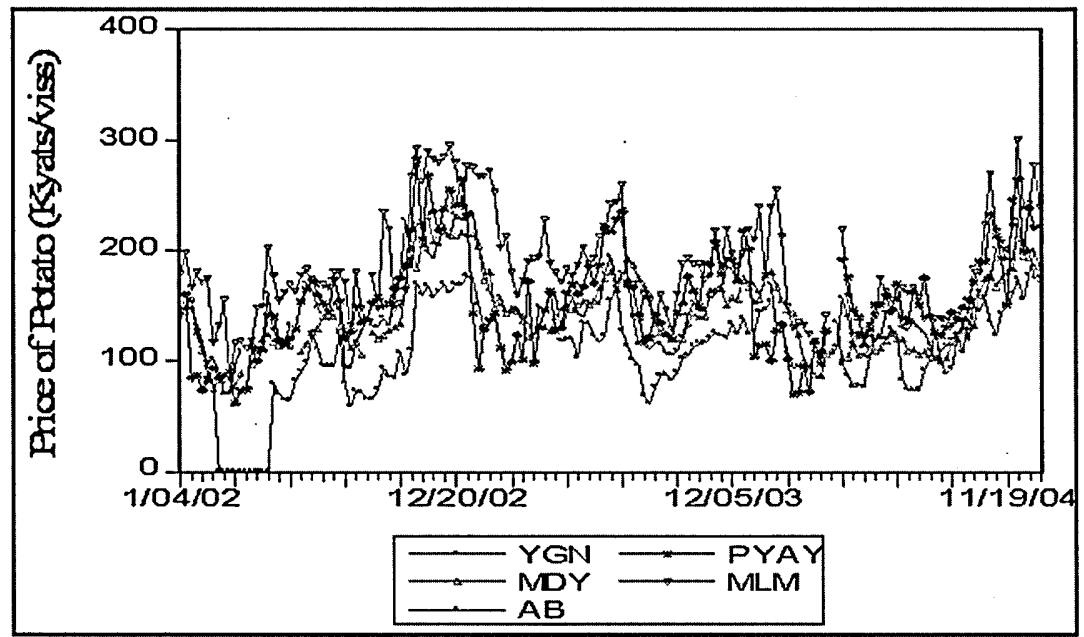

Fig. 3d. Potato price series of different market places, 2002-2004 


\section{METHODOLOGICAL FRAMEWORK}

The Johansen likelihood estimation and testing approach for market integration bases on the following Vector Auto-Regression (VAR) Model:

$$
\Delta x_{t}=\sum_{i=1}^{p-1} \Gamma_{i} \Delta x_{t-i}+\Pi x_{t-p}+\varepsilon_{t}
$$

Where:

$$
\begin{aligned}
x_{t} & =n \times 1 \text { vector of variables }\left(x_{1 t}, \cdots x_{n t}\right)^{\prime}: \text { [price of } n \text { market places] } \\
p & =\text { the number of lag to be determined } \\
\Gamma_{i}, \Pi= & \text { short-run and long-run parameter matrices to be determined } \\
\varepsilon_{t}= & \text { error terms }
\end{aligned}
$$

The test will be done step by step. The first step. in the analysis is to pre-test the order of integration of each variable, using Augmented Dickey Fuller (ADF) Test. The test based on the following equation:

$$
x_{t}=\alpha+\gamma x_{t-1}+\varepsilon_{t}
$$

If $\gamma=1, x$ is a non-stationary series (a random walk with drift); if the process is started at some point, the variance of $x$ increases steadily with time and goes to infinity. If the absolute value of $\gamma$ is greater than one, the series is explosive. The test is carried out by subtracting $x_{t-1}$ from both sides of the equation,

$$
\begin{aligned}
& x_{t}-x_{t-1}=\alpha+(\gamma-1) x_{t-1}+\varepsilon_{t} \\
& \Delta x_{t}=\alpha+\delta x_{t-1}+\varepsilon_{t}
\end{aligned}
$$

where, $\delta=\gamma-1$ and the null and alternative hypotheses are

$$
H_{0}: \delta=0, \quad H_{A}: \delta<0
$$

The ADF approach controls for higher-order correlation by adding lagged difference terms of the dependent variable to the right-hand side of the regression:

$$
\Delta x_{t}=\alpha+\delta x_{t-1}+\sum_{k=1}^{p} \gamma_{k} \Delta x_{t-k}+\varepsilon_{t}
$$

In taking $\mathrm{ADF}$ test, both a constant and trend should be included in the test regression, if the series seems to contain a trend. If the series does not exhibit any trend and has a nonzero mean, only a constant should be included in the regression. If the series seems to be fluctuating around a zero mean, neither a constant nor a trend should be included in the test regression.

The second step in the analysis is to define the lag length. In working with several time series, the interdependence between them should be taken into account. The lag length, at which the prices are mostly integrated, is defined by using VAR on the differenced series. The results of co-integration tests can be quite sensitive to these lag 
lengths.

The simple form of VAR is:

$$
x_{t}=A_{1} x_{t-1}+A_{2} x_{t-2}+\cdots+A_{p} x_{t-p}+\varepsilon_{t}
$$

where $x_{t}=n \times 1$ vector of variables $\left(x_{1 t}, x_{2 t} \cdots, x_{n t}\right)$

$A_{i}=n \times n$ matrix of coefficients

$\varepsilon_{t}=n \times 1$. vector of error terms

By subtracting $x_{t-1}$ from each side, equation (5) can be put into a more usable from.

$$
\Delta x_{t}=\left(A_{1}-I\right) x_{t-1}+A_{2} x_{t-2}+\cdots+A_{p} x_{t-p}+\varepsilon_{t}
$$

By adding and subtracting, $\left(A_{1}-I\right) x_{t-2}$ it obtains;

$$
\Delta x_{t}=\left(A_{1}-I\right) \Delta x_{t-1}+\left(A_{2}+A_{1}-I\right) x_{t-2}+\cdots+A_{p} x_{t-p}+\varepsilon_{\imath}
$$

By continuing this fashion, we obtain equation 1.

$$
\Delta x_{t}=\sum_{i=1}^{p-1} \Gamma_{i} \Delta x_{t-i}+\Pi x_{t-p}+\varepsilon_{t}
$$

where

$$
\begin{aligned}
& \Gamma_{i}=\sum_{j=1}^{i} A j-I \\
& \Pi=\sum_{i=1}^{p} A i-I
\end{aligned}
$$

In the equation (8), the rank of, $\Pi$ which is equal to the number of linearly independent co-integrating vectors that exist in the equilibrium system, becomes the main feature. If $\Pi$ has full rank, all the elements of $x_{t}$ are stationary. If $\Pi$ is zero, they all are integrated. In intermediate cases, if rank $(\Pi)=1$, there is a single cointegrating vector and the expression $\Pi x_{t-p}$ is the error-correction factor. For other cases in which $1<$ rank (II) $<\mathrm{n}$, there are multiple cointegrating vectors (Walter Enders, 1995).

The number of distinct cointegrating vectors can be obtained by checking the significance of the characteristic roots (Walter Enders, 1995), since the rank of a matrix is equal to the number of its characteristic roots that differ from zero. The number of characteristic roots can be obtained using the following two test statistics:

$$
\begin{aligned}
& \lambda_{\text {trace }}(r)=-T \sum_{i-r+1}^{n} \operatorname{In}\left(1-\hat{\lambda_{i}}\right) \\
& \lambda_{\max }(r, r+1)=-\operatorname{TIn}\left(1-\hat{\lambda_{r+1}}\right)
\end{aligned}
$$

where $\hat{\lambda_{i}}=$ the estimated values of the characteristic roots (also called eigenvalues) 
obtained from the estimated $\Pi$ matrix

$\mathrm{T}=$ the number of usable observations

After the number of co-integrating vectors has been defined, restrictions on these co-integrating vectors are tested. For this step, Johansen defined the two matrices $\alpha$ and $\beta$, both of dimension $(n \times r)$, where $r$ is the rank of $\Pi$, such that: $\Pi=\alpha \beta$,

The matrix $\beta$ is the matrix of co-integrating parameters, and the matrix $\alpha$ the matrix of weights (the speed of adjustment parameters) with which each co-integrating vector enters the $\mathrm{n}$ equations of the VAR (Walter Enders, 1995). Due to the cross-equation restrictions, it is not possible to estimate $\alpha$ and $\beta$ using OLS. However, with maximum likelihood estimation, it is possible to (1) estimate as an error-correction model; (2) determine the rank of $\Pi ;(3)$ use the $r$ most significant cointegrating vectors to form $\beta^{\prime}$; (4) select $\alpha$ such that $\Pi=\alpha \beta^{\prime}$ (Walter Enders, 1995).

\section{RESULT AND DISCUSSION OF THE TEST}

\section{Step 1. Testing for stationary}

Pre-testing all variables to assess their order of integration is a good practice. Using $\mathrm{ADF}$ test, the orders of integration of the variables are determined. Although forms of the Johansen tests can detect differing orders of integration, it is wise not to mix variables with different orders of integration (Walter Enders, 1995). The ADF equation (4) has been used with the hypotheses of $H_{0}: \delta=0$, and $H_{A}: \delta<0$. The results of the test on the variables with optimal lag length, having minimum Schwartz criterion are shown in table 1.

For all the price series, the unit root test (with an intercept) showed that the coefficients of $x_{t-1}$ were not significantly different from zero and so none of the price series was stationary. Furthermore, the unit root test on first differences (without an intercept) confirmed the opposite, which lead us to conclude that all series were integrated of order 1. This result implied that taking first differences as variables in the model will eliminate the stochastic trend in the nominal series.

\section{Step 2: Testing for the lag length}

In the VAR analysis, Akaike information criterion (AIC) and Schwarz criterion (SC) are used to select a suitable lag length. The results of the test can be quite sensitive to the lag length so it is important to be careful. Begin with the longest lag length deemed reasonable and test whether the lag length can be shortened (Walter Enders, 1995). The lag length defined by the smallest value for both AIC and SC is shown in the following tables.

From the above tables, it could be concluded in general that the present price changes were not correlated with their own price change in the previous period. However, in particular, the change of YGN current price was highly correlated with its price change in previous period for very perishable crops, like tomato and cabbage.

\section{Step 3: Determining the number of co-integrating equations}

The main task in this step is to determine the rank $r$ and to estimate the co-integrating equations. Using Johansen co-integration test available in EVIEWS, the rank of II can be determined. EVIEWS provides the critical values for the trace statistic 
Table 1. Unit root test on vegetable price series in different market places in MYANMAR.

\begin{tabular}{|c|c|c|c|c|c|c|c|}
\hline \multirow{2}{*}{$\begin{array}{c}\text { Market } \\
\text { Place }\end{array}$} & \multirow{2}{*}{ Observations } & \multicolumn{3}{|c|}{ Unit root-test on price levels } & \multicolumn{3}{|c|}{ Unit root-test on first differences } \\
\hline & & $\mathrm{ADF}$ & $\mathrm{d}$ & t-value & $\mathrm{ADF}$ & $\mathrm{d}$ & t-value \\
\hline \multicolumn{8}{|l|}{ TOMATO } \\
\hline Yangon (YGN) & 150 & $\mathrm{ADF}(0)$ & -0.083 & -2.468 & $\operatorname{ADF}(0)$ & -0.967 & -11.696 \\
\hline Mandalay (MDY) & 150 & $\mathrm{ADF}(0)$ & -0.107 & -2.935 & $\operatorname{ADF}(0)$ & -0.929 & -11.179 \\
\hline Aung Ban (AB) & 104 & $\mathrm{ADF}(0)$ & -0.211 & -3.466 & $\mathrm{ADF}(0)$ & -0.997 & -9.512 \\
\hline Wetpoke (WP) & 89 & $\operatorname{ADF}(1)$ & -0.038 & -1.078 & $\mathrm{ADF}(0)$ & -1.086 & -11.881 \\
\hline Mawlamying (MLM) & 129 & $\mathrm{ADF}(1)$ & -0.088 & -1.897 & $\operatorname{ADF}(0)$ & -1.146 & -13.211 \\
\hline \multicolumn{8}{|l|}{ CABBAGES } \\
\hline Yangon (YGN) & 155 & ADF (1) & -0.286 & -4.295 & $\mathrm{ADF}(1)$ & -1.62 & -12.368 \\
\hline Mandalay (MDY) & 154 & $\mathrm{ADF}(0)$ & -0.178 & -3.934 & $\mathrm{ADF}(0)$ & -1.133 & -14.036 \\
\hline Aung Ban (AB) & 115 & $\mathrm{ADF}(0)$ & -0.164 & -3.118 & $\mathrm{ADF}(0)$ & -1.046 & -10.921 \\
\hline Mawlamying (MLM) & 145 & $\mathrm{ADF}(0)$ & -0.302 & -5.047 & $\mathrm{ADF}(1)$ & -1.616 & -12.251 \\
\hline \multicolumn{8}{|l|}{ ONION } \\
\hline Yangon (YGN) & 156 & $\operatorname{ADF}(0)$ & -0.042 & -1.81 & $\mathrm{ADF}(0)$ & -0.947 & -11.735 \\
\hline Mandalay (MDY) & 154 & $\mathrm{ADF}(0)$ & -0.031 & -1.537 & $\mathrm{ADF}(0)$ & -0.979 & -12.031 \\
\hline Pyay (PYAY) & 151 & $\mathrm{ADF}(1)$ & -0.088 & -2.522 & $\mathrm{ADF}(0)$ & -1.083 & -13.504 \\
\hline Mawlamying (MLM) & 146 & $\mathrm{ADF}(1)$ & -0.057 & -2.214 & $\mathrm{ADF}(0)$ & -0.801 & -9.848 \\
\hline \multicolumn{8}{|l|}{ POTATO } \\
\hline Yangon (YGN) & 152 & $\mathrm{ADF}(0)$ & -0.109 & -2.884 & $\operatorname{ADF}(0)$ & -1.071 & -13.056 \\
\hline Mandalay (MDY) & 148 & $\mathrm{ADF}(0)$ & -0.054 & -1.903 & $\operatorname{ADF}(0)$ & -0.855 & -10.259 \\
\hline Aung Ban (AB) & 131 & $\mathrm{ADF}(0)$ & -0.078 & -2.103 & $\mathrm{ADF}(0)$ & -0.975 & -11.145 \\
\hline Pyay (PYAY) & 153 & $\mathrm{ADF}(0)$ & -0.179 & -3.787 & $\operatorname{ADF}(1)$ & -1.346 & -10.917 \\
\hline Mawlamying (MLM) & 145 & $\mathrm{ADF}(2)$ & -0.133 & -2.617 & $\mathrm{ADF}(1)$ & -1.337 & -11.061 \\
\hline
\end{tabular}

Note : - In the column ADF the number of lags that was allowed for in the unit root test is indicated in brackets, based on the Schwartz criterion. ADF analysis was carried out in EVIEWS.

- Critical value of $\mathrm{t}$ statistics: $\mathrm{t}=-2.88,5 \%$ level of significance.

Source: - Weekly price series from January 2002 to December 2004. Market Information Service Project, Department of Agricultural Planning, Ministry of Agriculture and Irrigation, Myanmar.

Table 2a. VAR analysis on tomato price series in different market places.

\begin{tabular}{|c|c|c|c|c|c|}
\hline TOMATO & $\triangle Y G N(-6)$ & $\triangle M D Y(-6)$ & $\triangle A B(-6)$ & $\Delta W P(-6)$ & $\triangle M L M(-6)$ \\
\hline$\triangle Y G N$ & $\begin{array}{c}-0.357 \\
(-2.121)\end{array}$ & $\begin{array}{c}0.249 \\
(1.745)\end{array}$ & - & - & - \\
\hline$\triangle M D Y$ & - & - & - & - & - \\
\hline$\triangle A B$ & - & $\begin{array}{c}-0.441 \\
(-3.589)\end{array}$ & $\begin{array}{c}0.283 \\
(1.857)\end{array}$ & - & $\begin{array}{c}0.313 \\
(2.251)\end{array}$ \\
\hline$\triangle W E T$ & - & - & - & - & - \\
\hline$\triangle M L M$ & - & - & - & $\begin{array}{c}-0.507 \\
(-1.805)\end{array}$ & - \\
\hline
\end{tabular}

Note: The results of the VAR analysis are based on six lags (the AIC and SC are smallest) All figures in parenthesis are t-values, non significant values are omitted 
Table 2b. VAR analysis on cabbage price series in different market places.

\begin{tabular}{ccccc}
\hline CABBAGE & $\triangle Y G N(-12)$ & $\triangle M D Y(-12)$ & $\triangle A B(-12)$ & $\triangle M L M(-12)$ \\
\hline \multirow{2}{*}{$\triangle Y G N$} & -0.331 & 0.413 & -0.716 & - \\
& $(-3.526)$ & $(2.203)$ & $(-3.945)$ & 0.183 \\
$\triangle M D Y$ & - & - & -0.284 & $(2.054)$ \\
& & - & $-2.6)$ & - \\
$\triangle A B$ & - & - & - & -0.303 \\
$\triangle M L M$ & - & & & $(-2.227)$ \\
\hline
\end{tabular}

Note: The results of the VAR analysis are based on twelve lags (the AIC and SC are smallest) All figures in parenthesis are t-values, non significant values are omitted

Table 2c. VAR analysis on Onion price series in different market places.

\begin{tabular}{ccccc}
\hline ONION & $\triangle Y G N(-1)$ & $\triangle M D Y(-1)$ & $\triangle P Y A Y(-1)$ & $\Delta M L M(-1)$ \\
\hline \multirow{2}{*}{$\triangle Y G N$} & - & - & 0.19 & 0.337 \\
& - & - & $(3.239)$ & $(4.324)$ \\
$\triangle M D Y$ & - & - & - & 0.236 \\
& & & -0.239 & 0.433 \\
$\triangle P Y A Y$ & - & -0.278 & $(-2.555)$ & $(3.474)$ \\
& & $-1.798)$ & - & - \\
\hline$M L M$ & & & \\
& & & & \\
\hline
\end{tabular}

Note: The results of the VAR analysis are based on one lag (the AIC and SC are smallest) All figures in parenthesis are $t-$ values, non significant values are omitted

Table 2d. VAR analysis on potato price series in different market places.

\begin{tabular}{|c|c|c|c|c|c|}
\hline POTATO & $\triangle Y G N(-1)$ & $\Delta M D Y(-1)$ & $\triangle A B(-1)$ & $\triangle P Y A Y(-1)$ & $\Delta M L M(-1)$ \\
\hline$\triangle Y G N$ & - & - & - & $\begin{array}{c}0.189 \\
(3.175)\end{array}$ & - \\
\hline$\triangle M D Y$ & $\begin{array}{c}0.25 \\
(4.038)\end{array}$ & - & - & - & $\begin{array}{c}-0.075 \\
(-1.995)\end{array}$ \\
\hline$\triangle A B$ & - & $\begin{array}{c}0.364 \\
(2.475)\end{array}$ & - & - & - \\
\hline$\triangle P Y A Y$ & - & $\begin{array}{c}0.382 \\
(1.689)\end{array}$ & - & - & - \\
\hline$\triangle M L M$ & - & $\begin{array}{c}0.539 \\
(-2.389)\end{array}$ & - & - & $\begin{array}{c}-0.332 \\
(-3.453)\end{array}$ \\
\hline
\end{tabular}

Note: The results of the VAR analysis are based on one lag (the AIC and SC are smallest) All figures in parenthesis are t-values, non significant values are omitted 
Table 3. Johansen's likelihood ratio test for the number of co-integrating vectors.

\begin{tabular}{|c|c|c|c|c|c|}
\hline $\begin{array}{l}\text { Null } \\
\text { Hypothesis }\end{array}$ & $\begin{array}{l}\text { Alternative } \\
\text { Hypothesis }\end{array}$ & $\begin{array}{l}\text { Likelihood } \\
\text { Ratio }\end{array}$ & $\begin{array}{l}5 \% \text { Critical } \\
\text { Value }\end{array}$ & $\begin{array}{l}1 \% \text { Critical } \\
\text { Value }\end{array}$ & $\begin{array}{l}\text { Hypothesized No. of } \\
\text { Cointegrating Equation (s) }\end{array}$ \\
\hline \multicolumn{6}{|l|}{ TOMATO } \\
\hline$r=0$ & $\mathbf{r}>0$ & 46.27338 & 59.46 & 66.52 & None \\
\hline $\mathrm{r}=1$ & $\mathbf{r}>1$ & 24.04544 & 39.89 & 45.58 & At most 1 \\
\hline$r=2$ & $\mathbf{r}>2$ & 10.07858 & 24.31 & 29.75 & At most 2 \\
\hline $\mathrm{r}=3$ & $r>3$ & 3.157198 & 12.53 & 16.31 & At most 3 \\
\hline $\mathrm{r}=4$ & $\mathrm{r}>4$ & 0.532847 & 3.84 & 6.51 & At most 4 \\
\hline \multicolumn{6}{|c|}{ L. R. rejects any cointegration at $5 \%$ significance level } \\
\hline \multicolumn{6}{|l|}{ CABBAGE } \\
\hline $\mathbf{r}=0$ & $r>0$ & 70.07956 & 39.89 & 45.58 & None** \\
\hline$r=1$ & $\mathbf{r}>\mathbf{1}$ & 31.90404 & 24.31 & 29.75 & At most $1^{* *}$ \\
\hline$r=2$ & $r>2$ & 12.02514 & 12.53 & 16.31 & At most 2 \\
\hline$r=3$ & $r>3$ & 0.340288 & 3.84 & 6.51 & At most 3 \\
\hline \multicolumn{6}{|l|}{ ONION } \\
\hline $\mathbf{r}=0$ & $\mathrm{r}>0$ & 206.7055 & 39.89 & 45.58 & None** \\
\hline $\mathrm{r}=1$ & $\mathrm{r}>1$ & 83.49215 & 24.31 & 29.75 & At most $1^{* *}$ \\
\hline $\mathbf{r}=\mathbf{2}$ & $\mathbf{r}>\mathbf{2}$ & 25.54185 & 12.53 & 16.31 & At most $2 * *$ \\
\hline$r=3$ & $r>3$ & 1.024281 & 3.84 & 6.51 & At most 3 \\
\hline \multicolumn{6}{|l|}{ POTATO } \\
\hline $\mathrm{r}=0$ & $r>0$ & 184.0763 & 59.46 & 66.52 & None** \\
\hline $\mathrm{r}=1$ & $r>1$ & 96.28402 & 39.89 & 45.58 & At most $1^{* *}$ \\
\hline$r=2$ & $r>2$ & 44.6224 & 24.31 & 29.75 & At most $2^{* *}$ \\
\hline $\mathbf{r}=\mathbf{3}$ & $\mathbf{r}>\mathbf{3}$ & 15.54213 & 12.53 & 16.31 & At most $3^{* *}$ \\
\hline $\mathrm{r}=4$ & $r>4$ & 0.114436 & 3.84 & 6.51 & At most 4 \\
\hline
\end{tabular}

Note: If the value of Likelihood Ratio exceeds the critical values, we reject the null hypothesis and accept the alternative of more co-integrating vectors.

Table 4. Estimation of Long-run price integration of some selected vegetables in Myanmar.

\begin{tabular}{|c|c|c|c|c|}
\hline CABBAGE & YGN & $\begin{array}{c}=+0.525 \mathrm{MDY} \\
(1.48) \mathrm{ns}\end{array}$ & $\begin{array}{c}-1.587 \text { MLM } \\
(-5.502)^{* * *}\end{array}$ & CointEq (1) \\
\hline ONION & $\begin{array}{l}\text { YGN } \\
\text { MDY }\end{array}$ & $\begin{aligned}=- & 0.931 \text { PYAY } \\
& (-11.619)^{* * *} \\
=- & 0.981 \text { PYAY } \\
& (-7.785)^{* * *}\end{aligned}$ & $\begin{array}{l}-0.126 \mathrm{MLM} \\
(-1.901)^{*} \\
+0.008 \mathrm{MLM} \\
(0.073) \mathrm{ns}\end{array}$ & $\begin{array}{l}\text { CointEq (1) } \\
\text { CointEq (2) }\end{array}$ \\
\hline POTATO & $\begin{array}{l}\text { YGN } \\
\text { MDY } \\
\mathrm{AB}\end{array}$ & $\begin{aligned}=- & 0.183 \text { PYAY } \\
& (-1.073) \mathrm{ns} \\
=- & 0.207 \text { PYAY } \\
& (0.883) \mathrm{ns} \\
=-2.542 \mathrm{PYAY} & (-2.266)^{* *}\end{aligned}$ & $\begin{array}{c}-0.635 \mathrm{MLM} \\
(-4.472)^{* * *} \\
-0.595 \mathrm{MLM} \\
(-3.045)^{* * *} \\
+1.518 \mathrm{MLM} \\
(1.626) \mathrm{ns}\end{array}$ & $\begin{array}{l}\text { CointEq (1) } \\
\text { CointEq (2) } \\
\text { CointEq (3) }\end{array}$ \\
\hline
\end{tabular}

Note: All figures in parenthesis (...) are t-values; $* * *=$ significant at $1 \%, * *=$ significant at $5 \%, *=$ significant at $10 \%, \mathrm{~ns}=$ not significant. 
( $\lambda_{\text {trace }}$ ) reported by Osterwald-Lenum (1992). The rank of $\Pi$, determined by Likelihood Ratio (LR) test statistics, can be seen in table 3.

The results of $\lambda_{\text {trace }}$ test from table indicated that there was no co-integrating equation for tomato at $95 \%$ significant level. However, the test could define the rank of $\Pi: 1$ for cabbage; 2 for onion; at 99\% significant level and 3 for potato at 95\% significant level.

\section{Step 4: Testing for long-run price integration using Johansen's co-integration test}

For the long-run price co-integration in Myanmar, the following co-integrating equations are normalized according to the rank, defined in step 3. One co-integrating equation is obtained for cabbage by normalizing with respect to YGN price; two co-integrating equations are obtained for onion by normalizing with respect to YGN and MDY prices; and three co-integrating equations are obtained for potato by normalizing with respect to YGN, MDY and $\mathrm{AB}$ prices. The normalized equations are shown in table (4).

The results from step 3 indicated the lack of integration for tomato in Myanmar. The results of long-run price integration by Johansen Likelihood test, could be explained that Yangon was integrated with all of the markets to which it distributed the commodities as the transit market. But it was not integrated with its supply markets, like Mandalay and Aung-ban in the case of cabbage. Aung-ban is the major production area for cabbage during the rainy season. However, the price of production area (AB) and the consumption area (YGN) was not integrated because of seasonality of regional production. Mandalay and Aung-ban were also integrated with the markets, to which they supply, which could be seen in the co-integrating equations of onion and potato. In the case of onion, Yangon was highly integrated with both Pyay and Malawmyine Markets, but Mandalay was integrated only with Pyay market, which showed that the longer distance made the weaker integration. This fact was also explained in the case of potato that Aung-ban cannot be integrated with Mawlawmyine market.

\section{Step 5: Testing for short-run integration with a vector error correction model}

Testing for short-run integration can be incorporated in the Vector Error Correction Model (VECM) using the same price series, only when long-run integration is observed. A principal feature of co-integrated variables is that their time paths are influenced by the extent of any deviation from long-run equilibrium (Walter Anders, 1995). After all, if the system is to return to the long-run equilibrium, the movement of at least some of the variables must respond to the magnitude of the disequilibrium (Walter Anders, 1995). The short-run equation for a single element takes the form,

$$
\Delta x_{t}=\sum_{i=1}^{p-1} \Gamma_{i} \Delta x_{(t-i)}+\ldots .+\varepsilon_{t}
$$

By $\Gamma_{i}$, the dynamics of partial short-run adjustment on the deviation from the long-run equilibrium can be estimated. The larger the coefficients of the co-integrating relations in the regression, the stronger the reaction of the markets in the short-run. The short-run dynamics are presented in the following tables.

The above tables showed that almost all markets reacted on the long-run co-integrating equations. In the case of cabbage (table 5a), Mawlamyine was the 
strongest follower, and Yangon was the second strongest follower of the co-integrating equation, having the coefficient of 0.156359 and 0.065438 , respectively. In the case of onion (table 5b), Yangon was the strongest follower of co-integrating equation 1, and Pyay was the strongest follower of the co-integrating equation 2 . In the case of potato (table 5c), Mawlamyine was the strongest follower of the co-integrating equation 1 and 2 , and Aung-ban was the strongest follower of the co-integrating equation 3. For the all, Yangon market could be said as a special market, as it reacted on all the co-integrating equations for all three commodities.

Table 5a. Estimation of Short-run Dynamics of Cabbage in Myanmar.

\begin{tabular}{lcccc}
\hline Error Correction: & D (YGN) & D (MDY) & D (AB) & D (MLM) \\
\hline \multirow{2}{*}{ CointEq (1) } & -0.065438 & -0.047933 & 0.047921 & 0.156359 \\
& $(0.04123)$ & $(0.02454)$ & $(0.02207)$ & $(0.03333)$ \\
& {$[-1.58700]$} & {$[-1.95302]$} & {$[\mathbf{2 . 1 7 1 6 6 ]}$} & {$[\mathbf{4 . 6 9 0 8 2}]$} \\
\hline
\end{tabular}

Note: All figures in parenthesis (...) are standard error and figures in [...] are t-values;

Table 5b. Estimation of Short-run Dynamics of Onion in Myanmar.

\begin{tabular}{lcccc}
\hline Error Correction: & D (YGN) & D (MDY) & D (PYAY) & D (MLM) \\
\hline CointEq (1) & -0.801338 & 0.052083 & -0.028215 & -0.150511 \\
& $(0.13971)$ & $(0.11858)$ & $(0.23368)$ & $(0.19629)$ \\
& {$[-\mathbf{5 . 7 3 5 7 3}]$} & {$[0.43923]$} & {$[-0.12074]$} & {$[\mathbf{- 0 . 7 6 6 7 9 ]}$} \\
CointEq (2) & 0.328431 & -0.30916 & 0.527133 & 0.143251 \\
& $(0.10548)$ & $(0.08952)$ & $(0.17643)$ & $(0.14819)$ \\
& {$[\mathbf{3 . 1 1 3 7 4}]$} & {$[\mathbf{- 3 . 4 5 3 4 2 ]}$} & {$[2.98782]$} & {$[0.96665]$} \\
\hline
\end{tabular}

Note: All figures in parenthesis (...) are standard error and figures in [...] are t-values;

Table 5c. Estimation of Short-run Dynamics of Potato in Myanmar.

\begin{tabular}{lccccc}
\hline Error Correction: & D (YGN) & D (MDY) & D (AB) & D (PYAY) & D (MLM) \\
\hline \multirow{2}{*}{ CointEq (1) } & -0.358204 & 0.248958 & 0.042085 & 0.053439 & 0.648706 \\
& $(0.11415)$ & $(0.07259)$ & $(0.12608)$ & $(0.19971)$ & $(0.17297)$ \\
& {$[-3.13798]$} & {$[\mathbf{3 . 4 2 9 6 9 ]}$} & {$[0.33379]$} & {$[0.26758]$} & {$[\mathbf{3 . 7 5 0 3 6}]$} \\
& & & & & \\
CointEq (2) & 0.151202 & -0.261476 & 0.1958 & 0.179687 & 0.492861 \\
& $(0.10149)$ & $(0.06454)$ & $(0.11209)$ & $(0.17756)$ & $(0.15378)$ \\
& {$[\mathbf{1 . 4 8 9 8 8}]$} & {$[\mathbf{- 4 . 0 5 1 6 7 ]}$} & {$[\mathbf{1 . 7 4 6 7 7}]$} & {$[1.01201]$} & {$[\mathbf{3 . 2 0 4 9 6}]$} \\
& & & & & \\
CointEq (3) & -0.073954 & -0.007224 & -0.133119 & 0.085586 & -0.06335 \\
& $(0.04008)$ & $(0.02549)$ & $(0.04427)$ & $(0.07013)$ & $(0.06074)$ \\
& {$[\mathbf{- 1 . 8 4 4 9 9 ]}$} & {$[-0.28340]$} & {$[\mathbf{- 3 . 0 0 6 7 7 ]}$} & {$[1.22041]$} & {$[\mathbf{- 1 . 0 4 2 9 9}]$} \\
\hline
\end{tabular}

Note: All figures in parenthesis (...) are standard error and figures in [...] are t-values; 
The significance and magnitude of the coefficients were consistent with demand and supply conditions in the country. The consumption and production districts are: - for cabbage, Mandalay and Mawlamyine are the most consumption districts and Aung-ban is the largest production district; for onion, Yangon and Pyay are the most consumption districts and Mandalay is the most production district; for potato, Yangon, Mandalay, Malawmyine are consumption districts and Aung-ban is the most production district. The most consumption district were the strongest follower of the co-integrating equations and the partial adjustment of price changes at those markets reacted significantly on the deviation from the long-run equilibrium.

\section{CONCLUSIONS}

Using weekly wholesale price data for three years, this paper has analyzed the spatial integration of vegetable markets in Myanmar, in order to understand its functioning.

From the results, it could be observed that very perishable crops - like tomato and cabbage prices - were not so much integrated. Actually, there was no integration for tomato. However, less perishable crops - like onion and potato - revealed that almost all markets were integrated. In addition, the longer the distance, the lesser the integration could be observed. These facts showed the weakness of market infrastructure leading to market inefficiency. Moreover, Regional production and food substitution made some markets segment.

Generally, the markets in deficit areas are integrated with the supply markets. Malawmying market showed this fact that it was highly integrated with Yangon market, which performed as the transit market. The price changes in the production areas did not have any measurable influence on the transit markets or consumption markets. For example, Aung-ban market was not integrated with Yangon market, as well as Mawlamyine market. Inefficient and irrelevant market information gives the producers difficulty for their production plan.

Although how to improve market efficiency cannot be assessed on the basis of price series alone, it can be suggested that there is plenty of room for improvement in the functioning of vegetable markets in Myanmar. More emphasis on investments in market infrastructure - trekking routes, rail, and road transport; strengthening cooperative marketing; establishing local assembly stations; and distributing reliable market information, etc. could significantly improve the efficiency of vegetable markets in Myanmar.

\section{REFERENCES}

Barret, C. B. 1996 Market Analysis Methods: Are Our Enriched Toolkits Well Suited to Enlivened Markets?. Amer. J. Agr. Econ., 78: 825-29

Cristopher Dougherty 1992 Introduction to Econometrics. Oxford University Press, Oxford (New York), pp. 348-352

Darné, O. 2003 Maximum likelihood seasonal cointegration tests for daily data. Economics Bulletin, 3(18): $1-8$

Fafchamps, M., and S. Gavian 1995 The Spatial Integration of Livestock Markets in Niger. Food Research Institute, Stanford University (Stanford)

Ferr, M. 2004 The Johansen Test and the Transitivity Property. Economics Bulletin, 3(27): 1-7

González-Rivera, G., S. M. Helfand 2001 The Extent, Pattern, and Degree f Market Integration: A 
Multivariate Approach for the Brazilian Rice Market. Amer. J. Agr. Econ., 83(3): 576-592

Johansen, S. 1991 Estimation and Hypothesis Testing of Cointegration Vectors in Gaussian Vector Autoregressive Models. Amer. J. Agr. Econ., 59(6): 1551-1580

Luu Thanh Duc Hai, C. Lutz and C. Praagman Rice Market Integration in the Mekong River Delta The successful liberalization of the domestic food market in Vietnam From the homepage of SOM theme B

Quantitative Micro Software 1994-1998 Eviews User's Guide (2"ut Edition). Quantitative Macro Software Press, U. S. A, pp. 300-335, 493-522

Ramanathan, R. 1989 Introductory Econometrics with applications (Third edition). The Dryden Press, Fort Worth (U. S. A), pp. 523-583

Ravallion, M. 1986 Testing Market Integration. Amer. J. Agr. Econ., 68: 102-109

Sephton, P. S. 2003 Spatial Market Arbitrage and Threshold Cointegration. Amer. J. Agr. Econ., 85(4): 1041-1046

Sexton, R. J., C. L. Kling, and H. F. Carman 1991 Market Integration, Efficiency of Arbitrage, and Imperfect Competition: Methodology and Application to U. S. Celery. Amer. J. Agr. Econ., 73: 568-580

Walter Enders 1995 Applied Econometric Time Series John Wiley \& Sons, Inc., U. S. A, pp. 211-421 